\title{
FAKTOR PENDUKUNG MENINGKATKAN PRESTASI SISWA
}

\author{
ANI MASRUFAH \\ Program Studi Teknik Lingkungan \\ Fakultas Teknik \\ Universitas Nahdlatul Ulama Sidoarjo \\ Email: ani.masrufah09@gmail.com
}

Pendidikan adalah suatu kegiatan pembentukan kesadaran dan kepribadian anak didik di samping transfer(Qori'ah, S., Sholikhah, S.A., Purnomo, A., \& Rosyidah, 2017) Prestasi merupakan sebuah istilah yang disematkan atas pencapaian atau usaha seseorang dalam bidang tertentu selama hidupnya. Prestasi juga dijadikan sebagai indikator untuk mengetahui letak potensi diri, oleh sebab itu semua orang wajib mempunyai prestasi dalam hidupnya meskipun hanya sekali. Menurut Suryabrata, 2006, prestasi didefinisikan sebagai nilai yang merupakan perumusan terakhir yang dapat diberikan oleh guru mengenai kemajuan atau prestasi belajar siswa selama masa tertentu (Rifki, 2008) . Berdasarkan uraian diatas dapat dikatakan bahwa prestasi belajar adalah usaha yang dicapaioleh siswa dengan melibatkan seluruh potensi yang dimilikinya setelah siswa tersebut melakukan kegiatan belajar Pencapaian hasil belajar tersebut dapat diketahui dengan mengadakan penilaian tes hasil belajar. Pendidikan Indonesia membutuhkan peningkatan akses, mutu dan relevansi pendidikan untuk memberi manfaat membangun bagi pendidikan dan rakyat Indonesia(Irawan, D. E., et, 2018) Penilaian diadakan untuk mengetahui sejauh mana siswa telah berhasil mengikuti pelajaran yang diberikan oleh guru. Prestasi bukanlah bentuk kesombongan diri, tetapi sebuah bentuk untuk menginspirasi orang lain. Sudah sewajarnya rasa minder kadang hadir di sudut perasaan, sangat tipis namun mampu mempengaruhi seseorang untuk mundur setelah yakin untuk maju, itu adalah cobaan bagi orang yang ingin bergerak dan berniat baik untuk mengembangkan diri. Prestasi, sesuatu yang sangat mudah membangkitkan rasa percaya diri seseorang, bagaimana tidak? Prestasi adalah pencapaian nyata yang tidak bisa disngkal orang lain berpendapat bahwa siswa perlu memahami apa yang diketahui dan apa yang diminta untuk memiliki kemampuan menjawab. (Rifki, 2008) menjelaskan bahwa perkembangan suatu bangsa erat hubungannya dengan masalah pendidikan.

\section{Internal}

Ngalim, 2010 menyatakan faktor-faktor yang mempengaruhi prestasi belajar adalah faktor dari dalam diri individu terdiri dari faktor fisiologis dan 
faktor psikologis (Rifki, 2008). Faktor fisiologis adalah kondisi jasmani dan kondisi panca indera sedangkan faktor psikologis adalah bakat, minat, kecerdasan, dan kemampuan kognitif. Faktor dari luar individu terdiri dari faktor lingkungan dan faktor instrumental. Faktor lingkungan adalah lingkungan sosial di mana seseorang berada pada lingkungan keluarga, sekolah, masyarakat, dan kelompok, sedangkan faktor instrumenal yaitu kurikulum, bahan, guru, sarana, administrasi. Faktor intrnal adalah faktor yang ada dalam individu yang sedang belajar, yaitu :

a. Semangat Belajar

Salah satu faktor internal dalam prestasi belajar yaitu semangat belajar, karena meskipun seseorang pelajar memiliki semangat yang tinggi dan keinginan yang kuat, pasti akan tetap merasakan kemalasan, mengalami keengganan dan kelalaian. Maka tunas semangat ini harus dipelihara secara terus menerus. Semangat belajar merupakan kekuatan mental yang mendorong terjadinya proses belajar. Lemahnya semangat atau tidak adanya semangat belajar akan melemahkan kegitan belajar, selanjutnya mutu belajar akan menjad rendah. Menurut (Moekijat, 2004) "Semangat adalah kemampuan sekelompok orang untuk bekerja sama dengan giat dan konsekuen dalam mencapai tujuan bersama". Bisa dikatakan bahwa semangat belajar adalah kemampuan untuk bekerja dengan giat dan konsekuen untuk memperoleh suatu perubahan tingkah laku dalam jangka waktu lama melalui latihan maupun pengalaman sehingga seseorang memiliki keterampilan, pengetahuan, sikap dan nilai.

b. Percaya diri

Pemahaman tentang hakekat percaya diri akan lebih jelas jika seseorang melihat langsung berbgai peristiwa yang dialami oleh dirinya sendiri atau orang lain. Rasa percaya diri sering dimaknai dengan rasa kemampuan individu dalam menyeimbangkan struktur kejiwaan yang ada pada diri individu tersebut, dengan kata lain percaya diri adalah individu yang mampu mengendalikan gejala emosional seperti takut dan sebagainya sehingga ia berani memposisikan pada hal yang seimbang. Berdasarkan berbagai peristiwa dan pengalamn tersebut bisa kita lihat bahwa gejl-gejala tingkah laku seseorang yang menggambarkan adanya rasa percaya diri atau tidak.

c. Bakat

Secara umum bakat adalah kemampuan potensial yang dimiliki seseorang untuk mencapai keberhasilan pada masa yang akan datang. Dengan demikian, sebetulnya setiap orang pasti memiliki bkat dalam arti potensi untuk mencapai prestasi sampai ketingkat tertentu sesuai dengan kapasitas masing-masing. Jadi secara global bakat itu mirip dengan intelgensi. Dalam perkembangan selanjutnya bakat diartikan sebagai 
kemampuan individu untuk melakukan tugas tertentu tanpa banyak bergantung pada upaya pendidikan dan latihan. Misalnya seorang siswa berbakat dalam bidang elektro, maka akan lebih mudah menyerap informasi, kemampuan dan keterampilan yang berhubungan dengan bidang elektro ketimbang siswa lainnya.

\section{Eksternal}

Faktor eksternal merupakan suatu komponen sistem yang ikut menentukan keberhasilan proses pendidikan. Faktor internal meliputi lingkungan keluarga maupun pergaulan. Kondisi lingkungan menjadi perhatian karena faktor ini sangat dekat dengan kehidupan sehari-hari siswayang sangat berpengaruh terhadap prestasi siswa. Saroni M, 2006 menjelaskan bahwa dalam lingkungan sosial berhubungan dengan interaksi antar personil yang ada di lingkungan pendidikan secara umum. (Nisa M,I, 2012) Faktor lingkungan adalah lingkungan sosial dimana seseorang berada pada lingkungan keluarga maupun pergaulannya untuk mempengaruhi kehidupannya. Menurut Hamalik O, 2000 "Lingkungan belajar adalah tempat untuk melakukan proses belajar sehingga terjalin komunikasi anak dan orang 5 dewasa untuk menjadikan anak lebih dewasa"( Nisa M,I, 2012). Sedangkan menurut Winkel, 1996 "Lingkungan belajar adalah tempat untuk memperoleh pemahaman, pengetahuan, ketrampilan dan sikap nilai yang mengantarkan kedewasaan kita" (Nisa M,I, 2012). Sehingga dapat dikatakan bahwa lingkungan belajar adalah tempat untuk melakukan proses belajar dan komunikasi untuk memperoleh pemahaman, pengetahuan ketrampilan dan sikap nilai yang mengantarkan kedewasaan. (Judiani Setditjen Pendidikan Dasar, 2011) menjelaskan bahwa dengan adanya pendidikan dan generasi penerus bangsa akan memajukan bangsa ini dengan mengamalkan apa yang telah di pelajari di bangku sekolah serta menghargai jasa guru-gurunya. Bijaksana dan pantang menyerah adalah kunci kesuksesan.

\section{a. Keluarga}

Pendidikan keluarga merupakan pengalaman pendidikan pertama bagi anak. Pendidikan keluarga juga merupakan dasar dari pendidikan anak sehingga untuk memperoleh pengetahuan dan pengalaman yang lain maka keluarga dengan kesadaran memberikan pendidikan yang lain pula yaitu dengan menyekolahkan anaknya.endidikan di sekolah memberikan motivasi dalam mengaktifkan anak didiknya sehingga tidak menutup kemungkinan banyak keanekaragaman problem yang dihadapi anak didiknya dengan latar belakang yang berbeda.

\section{b. Pergaulan}

Interaksi antar siswa dapat mempengaruhi hubungan atau pergaulan yang dapat membentuk kepribadian seseorang. Suryabrata, 2001 
menjelaskan bahwa pergaulan adalah jalinan hubungan sosial antara seseorang dengan orang lain sehingga terjadi saling mempengaruhi satu dengan lainnya. Pengaruh dari individu atau kelompok yang bermanfaat sedangkan dampak negatif dapat mengarahkan seseorang pada pergaulan bebas yang harus dihindari oleh setiap masyarakat khususnya bagi remaja (Papalia et, 2014). (Hadi, 2008) berpendapat bahwa pergaulan adalah kontak langsung antara satu individu dengan individu lain, termasuk di dalamnya pendidik dan siswa. Ahmadi et, 2007: mengemukakan pergaulan adalah kontak langsung antara satu individu dengan individu lain (Fahrur, 2016). Berdasarkan pernyataan-pernyataan di atas, didapat suatu kesimpulan bahwa yang dimaksud dengan pergaulan adalah hubungan atau interaksi antara seseorang dengan orang lain yang meliputi tingkah laku dan melibatkan orang lain.(Nahdiyah, K., 2017) menjelaskan bahwa Cari ilmu yang bermanfaat dan patuhi aturan-aturan yang ada. Bijaksana dan pantang menyerah dalam belajar adalah kunci kesuksesan. Pendidikan dan Akhlak yang baik melahirkan generasi yang baik juga

Grafik 1 menjelaskan jumlah sekolah berdasarkan jenjang dan status tahun 2016/2017

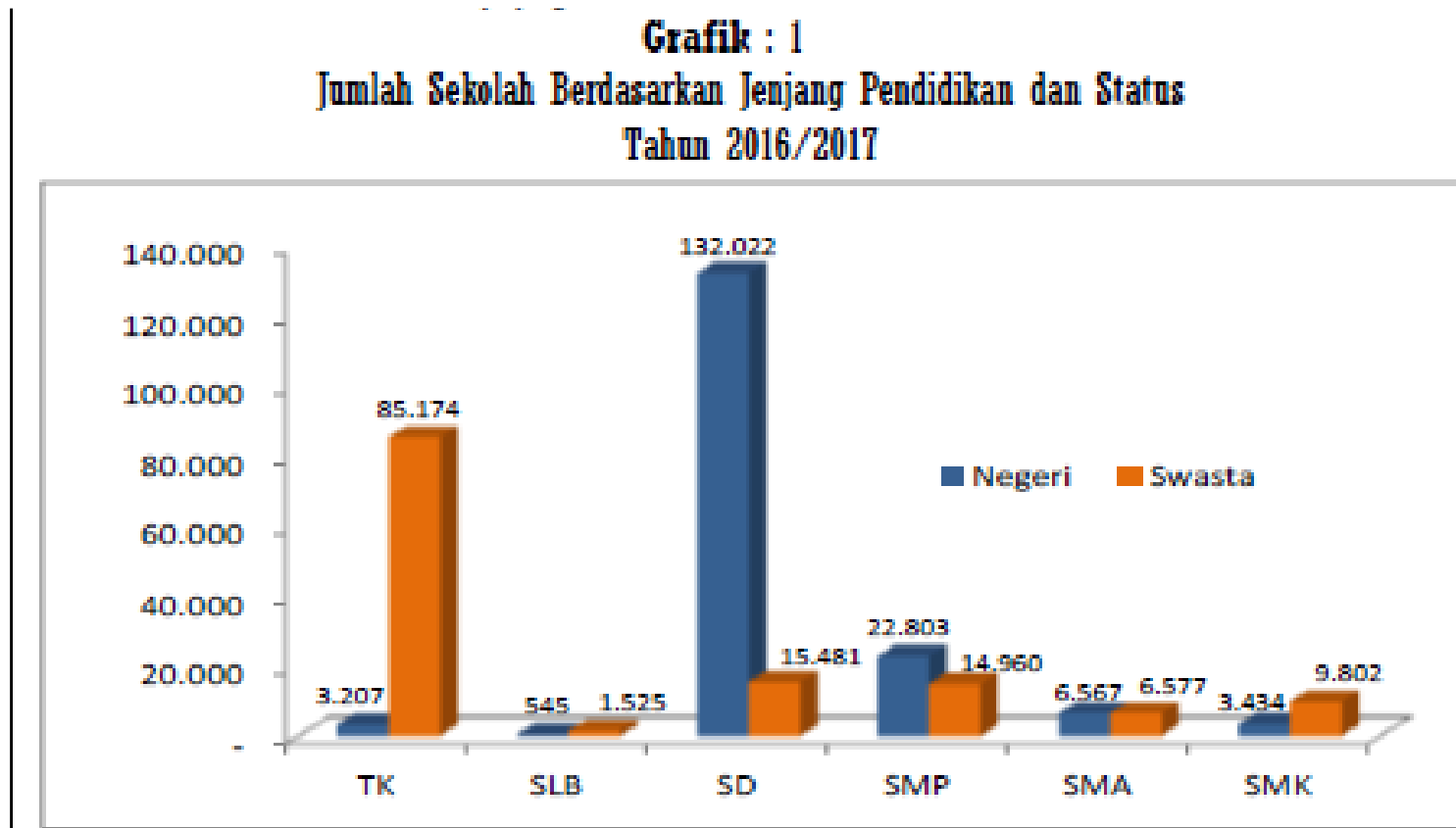

Pusat Data dan Statistíle Pendidikan dan Kebudayaan

TK Negri lebih sedikit dibanding TK Swasta yaitu 3.207 dengan 85.174.

SLB Negri lebih sedikit dibanding SLB Swasta yaitu 545 dengan 1.525

SD Negri lebih banyak dibanding SD Swasta yaitu 13.002 denga 15.481

SMP Negri lebih banyak dibanding SMP Swasta yaitu 22.803 dengan 14.960 
SMA Negri lebih sedikit dibanding SMA Swasta yaitu 6.567 dengan 6.577

SMK Negri lebih sedikit dibanding SMK Swasta yaitu 3.434 dengan 9.802

Grafik 2 menjelaskan tentang presentase siswa menurut jenis kelamin da jenjang Pendidikan

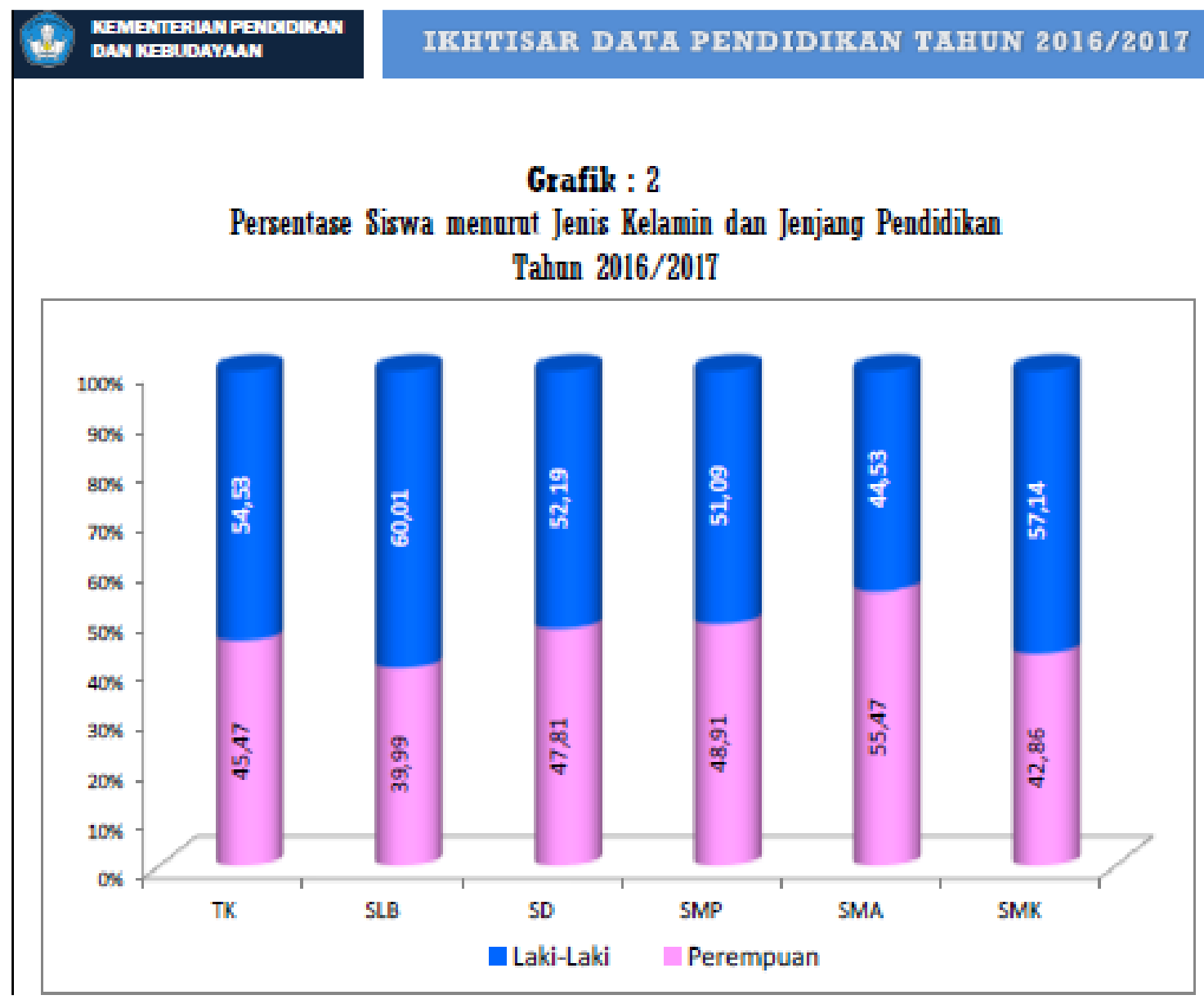

TK lebih banyak laki-laki dibanding perempuan yaitu 54,53\% dengan 45,47\% SLB lebih banyak laki-laki dibanding perempuan yaitu 60,01\% dengan 39,99\% SD lebih banyak laki-laki dibanding perempuan yaitu 52,19\% dengan 47,81\% SMP lebih banyak laki-laki dibanding perempuan yaitu 48,91\% dengan 51,09\% SMA lebih sedikit laki-laki dibanding perempuan yaitu $44,53 \%$ dengan $55,47 \%$ SMK lebih banyak laki-laki dibanding perempuan yaitu 57,14 \% dengan 42,86\%

\section{Kesimpulan}

Faktor pendukung meningkatkan prestasi siswa ada dua yaitu faktor internal dan faktor eksternal. Faktor internal meliputi semangat belajar, percaya 
diri, dan bakat. Sedangkan faktor eksternal meliputi lingkungan keluarga maupun pergaulan.

\section{Daftar Pustaka}

Fahrur, L. (2016). Artikel Skripsi Universitas Nusantara PGRI Kediri TeknikSistem Informasi simki.unpkediri.ac.id || 2||.

Irawan, D. E., Purnomo, A., Sutiksno, D. U., Abraham, J., Alamsyah, A., Saputra, D. H., Javandira, C., \& Rosyidah, E. (2018). Kajian Pendidikan Tinggi IDRI untuk DPR RI dan Ristek Dikti 2018. In Kajian Pendidikan Tinggi IDRI untuk DPR RI dan Ristek Dikti 2018. Sidoarjo.

Judiani Setditjen Pendidikan Dasar, S. (2011). Kreativitas Dan Kompetensi Guru Sekolah Dasar. Jurnal Pendidikan Dan Kebudayaan, 17(1), 1-6.

Lingkungan, D. A. N., \& Pada, B. (2012). Prestasi belajar ditinjau dari semangat belajar dan lingkungan belajar pada mahasiswa fkip-ums progdi pendidikan akuntansi angkatan 2009/2010.

Nahdiyah, K., Amrina, S., Purnomo, A., \& Rosyidah, E. (2017). Wirausaha PendidikanNo Title. In Wirausaha Pendidikan Indonesia Jilid 2. Sidoarjo.

Qori'ah, S., Sholikhah, S.A., Purnomo, A., \& Rosyidah, E. (2017). Wirausaha Pendidikan Indonesia Jilid 3. Sidoarjo.

Rifki, M. (2008). Pengaruh Rasa Percaya Diri Terhadap Prestsi Belajar Siswa di SMA ISLAM AL Maarif singosari Malang. 84. 